TAPROBANICA, ISSN 1800-427X. April, 2009. Vol. 01, No. 01: pp. 39-42.

(C) Taprobanica Nature Conservation Society, 146, Kendalanda, Homagama, Sri Lanka.

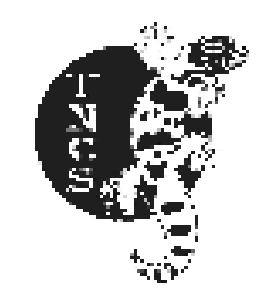

\title{
AN UNUSUAL MISLEAD COMMUNICATION BEHAVIOUR OF Duttaphrynus melanostictus (SCHNEIDER, 1799) (AMPHIBIA: BUFONIDAE) AND Polypedates cruciger BLYTH, 1852 (AMPHIBIA: RHACOPHORIDAE) AT A HUMAN HABITATION IN SRI LANKA
}

Submitted: 12 January 2009, Accepted: 15 January 2009

\author{
W. Gayan M. Edirisinghe ${ }^{1}$ and A. A. Thasun Amarasinghe ${ }^{2,3}$ \\ ${ }^{1}$ The Young Zoologists' Association of Sri Lanka, Department of National Zoological Gardens, Dehiwala, Sri \\ Lanka. \\ ${ }^{2}$ Taprobanica Nature Conservation Society, 146, Kendalanda, Homagama, Sri Lanka. \\ ${ }^{3}$ Corresponding author: aathasun@gmail.com
}

\begin{abstract} identify its partner easily.

\section{Introduction}

There are 109 species of amphibians in Sri Lanka and 92 of them are endemic. Also further new species will be described in the future (Meegaskumbura et al., 2002). These 109 species are classified under seven families; Ichthyophiidae,
\end{abstract}

Duttaphrynus melanostictus and Polypedatus cruciger are common amphibians in Sri Lanka, being sympatric in many habitats, while P. cruciger is endemic to the island. This is the first published observation on an unusual mislead communication behavior on D. melanostictus and P. cruciger at a human habitat in Sri Lanka. Considering the field observation, we can assume both D. melanostictus and P. cruciger males may accidentally catch almost immediately without identifying each other properly in their breeding periods. We suggest that these amphibians communicate with their unique call but their eyesight is not developed to

Key Words: Duttaphrynus melanostictus, Polypedatus cruciger, unusual communication behavior, Sri Lanka

Bufonidae, Dicroglossidae, Microhylidae, Ranidae, Nyctibatrachidae and Rhacophoridae (Frost et al., 2006). Family Bufonidae is one of the most common amphibian families in south and Southeast Asia (Pough et al., 2004). Bufonidae consists of 
three genera Bufo, Duttaphrynus and Adenomus, the genus Duttaphrynus consists of two species and among them one species is endemic to Sri Lanka (Frost, et al., 2006; Manamendra-Arachchi \& Pethiyagoda, 1998; Manamendra-Arachchi \& Pethiyagoda, 2006).

Duttaphrynus melanostictus is distinguished from all the other Sri Lankan Duttaphrynus species by having parietal ridges absent and two longitudinal rows of large warts which distributed all length of inter parotid area. Snout-vent length of mature males is 50.3-90.0 mm, gravid females 70.0-95.0 mm (Manamendra-Arachchi \& Pethiyagoda, 1998; Manamendra-Arachchi \& Pethiyagoda, 2006). The Family Rhacophoridae consists of 69 species belonging to three genera: Philautus, Polypedates and Rhacophorus. There are 5 species of genus Polypedatus in Sri Lanka. Four of them are endemic to the country include $P$. cruciger (Dutta \& Manamendra-Arachchi, 1996; Frost, et al., 2006).

Polypedatus cruciger, which is endemic to Sri Lanka, is distinguished from all the other Sri Lankan Polypedatus species by having the calcar absent and possessing a co-ossified skull. Snoutvent length of mature males is $50.0-59.8 \mathrm{~mm}$, gravid females 72.0-90.0 $\mathrm{mm}$ (Dutta \& Manamendra-Arachchi, 1996; ManamendraArachchi \& Pethiyagoda, 2006). This short communication is intended to provide information on an observation relating to unusual mislead communication behavior on Duttaphrynus melanostictus and P. cruciger at a human habitat in Sri Lanka. Both species are common in Sri Lanka and also sympatric in many habitats. This is the first record of an unusual mislead communication behavior involving $D$. melanostictus and $P$. cruciger.

\section{Observation}

The observations were made in Kesbewa (alt. $10 \mathrm{~m}$ a.s.1.) in Colombo district in Western province of Sri Lanka. The geographical coordinates of the study area are $06^{\circ} 40^{\prime} 54^{\prime \prime} \mathrm{N}$ and $80^{\circ} 00^{\prime} 34^{\prime \prime} \mathrm{E}$, approximately $200 \mathrm{~m}$ away from Kesbewa town. The observations were made by the naked eye, $2 \mathrm{~m}$ away from the toad and the tree-frog from 09:15 hr. to $10: 15 \mathrm{hr}$. No disturbances were made to animals during the time of observation. A mature male Duttaphrynus melanostictus was observed on $29^{\text {th }}$ March 2006 at about 09:15 hr., while it was puffing its vocal sac and calling sharp on the ground. The temperature and the humidity at that time was $29^{\circ} \mathrm{C}$ and $79 \%$. The weather was shady. Firstly the male
D. melanostictus jumped towards an artificial pond up to about one meter to the edge of the pond. At once a mature male Polypedatus cruciger jumped on to toad's back (Fig. 01).

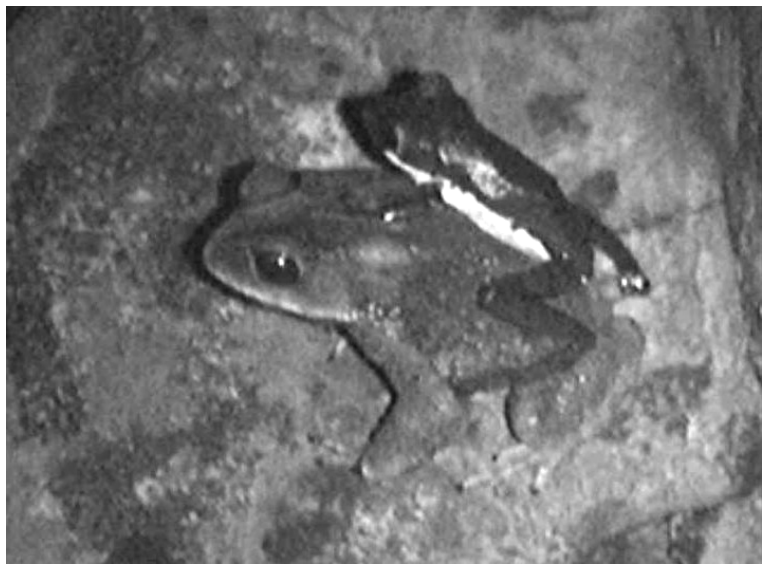

Fig. 01: The tree-frog jumped to toad's back

The male tree-frog stayed on the male toad's back for about ten minutes. During this time the toad tried to escape from the tree-frog. Finally the toad kicked the tree-frog and then the tree-frog jumped to in front of the toad on the ground (Fig. 02). Following, the toad jumped forward and caught the tree-frog tightly. Likewise, the toad stayed on the tree-frog's back for 5 minutes (Fig. 03). Afterwards, the tree-frog escaped from the toad and jumped again to its back. At this time the tree-frog stayed on the toad's back for about another five minutes. During this time, a female $P$. cruciger jumped near the unmatched couple (Fig. 04). Immediately the male toad jumped over and caught the second female tree-frog (Fig. 05) and gripped it tightly for about five minutes. After that, the toad released its grip and escaped. Then the tree-frog jumped into the pond and disappeared.

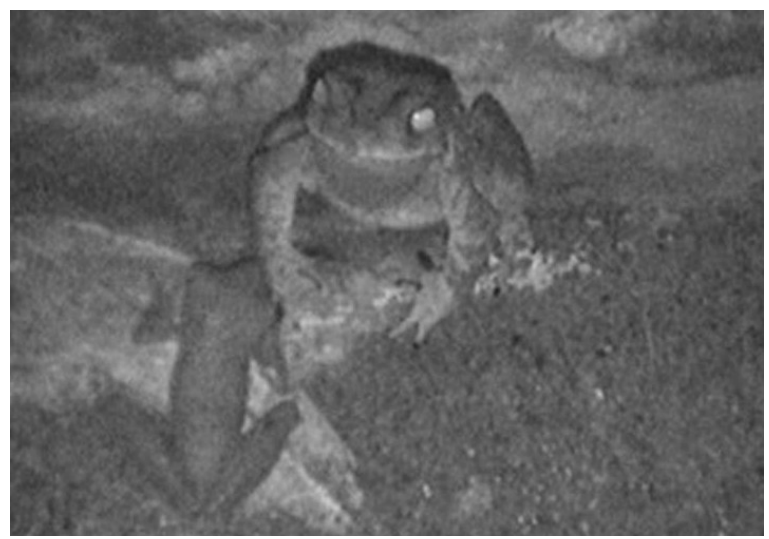

Fig. 02: The tree-frog jumped to in front of the toad 


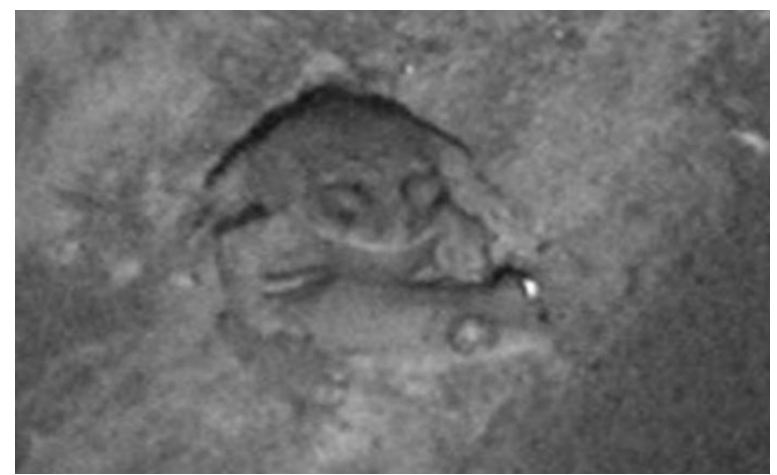

Fig. 03: The toad jumped forward and caught the treefrog tightly

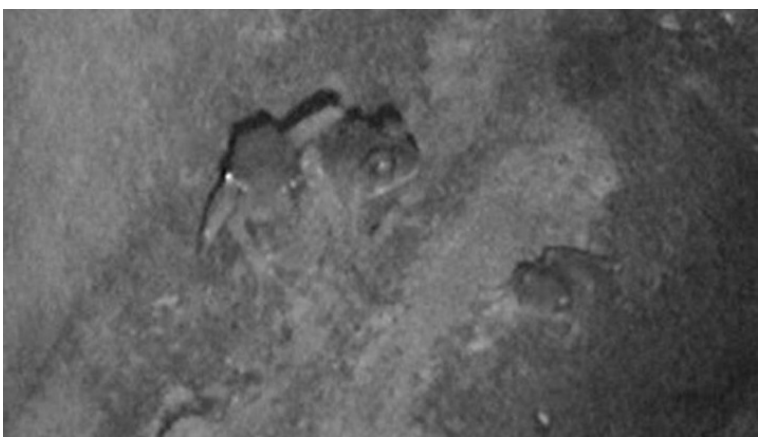

Fig. 04: the tree-frog escaped from the Toad, jumped again to its back and another tree-frog arrived

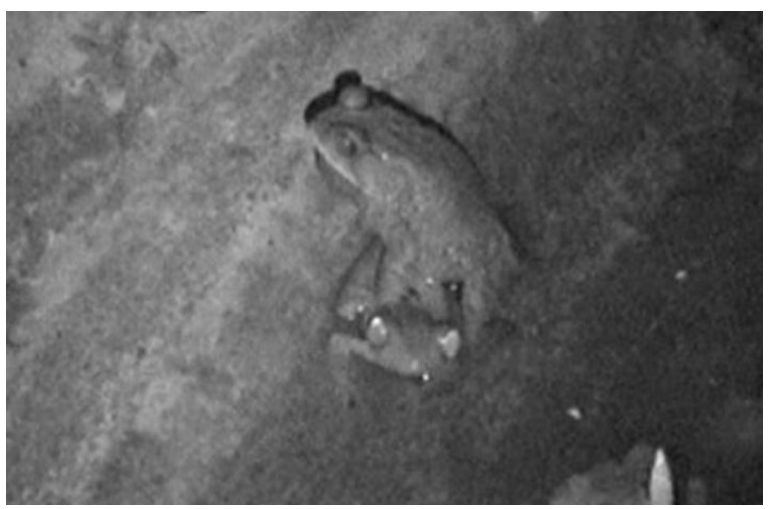

Fig. 05: The toad jumped over and caught the second female tree-frog

\section{Discussion}

According to Emerson (2001), Giacoma and Castellano (2001) and Pough et al. (2004) there are no records of that unusual type of mislead communication between two amphibian species belonging to two different families. This is the first documented observation of an unusual mislead communication behavior involving Duttaphrynus melanostictus and Polypedates cruciger in Sri Lanka. We assume this was a mistaken communication, which was made by both species. This observation demonstrates that this two species are clearly attracting their partners by calling, though both callings were made in the same time period. Both males of these species expected a female of their species but only a female $P$. cruciger came. So when the male $P$. cruciger spotted the $D$. melanostictus it perhaps recognized visually it as its mate. Therefore the male $P$. cruciger jumped to toad's back.

We could see the toad was not like this because it is a male. After dispatch Polypedates cruciger male from its back the male Duttaphrynus melanostictus saw the female $P$. cruciger and made the mistake again and grabbed it as its mate. After few minutes it may have realized the mistake and gave the female $P$. cruciger a chance to escape. We suggest these tree-frogs communicate with their unique call but their eyesight is not developed to identify its partner easily. After considering all the observations we could conclude that both $D$. melanostictus and $P$. cruciger males may catch each other immediately without identifying themselves properly in their breeding periods.

\section{Acknowledgements}

The authors wish to thank Enrique La Marca, Tzi Ming Leong and Mohomed M. Bahir for useful comments. And also we would also like to thank Suranjan Karunarathna (IUCN) and Dinesh Gabadage (TNCS) for their supports.

\section{Literature Cited}

Dutta, S. K. and K. N. Manamendra-Arachchi, 1996. The Amphibian Fauna of Sri Lanka. Wildlife Heritage Trust of Sri Lanka: 230.

Emerson, S. B., 2001. Male advertisement calls: behavioral variation and physiological processes. In: Ryan, M.J. (Ed.). Anuran Communication. Smithsonian institution press, Washington and London: 36-44.

Frost, D. R., T. Grant, J. Faivovich, R. H. Bain, A. Haas, C. F. B. Haddad, R. O. de Sá, A. Channing, M. Wilkinson, S. C. Donnellan, C. J. Raxworthy, J. A. Campbell, B. L. Blotto, P. Moler, R. C. Drewes, R. A. Nussbaum, J. D. Lynch, D. M. Green and W. C. Wheeler, 2006. The Amphibian Tree of Life. Bulletin of the American Museum of Natural History, 297: 1370 .

Giacoma, C. and S. Castellano, 2001. Advertisement call variation and speciation in the Bufo viridis 
complex. In: Ryan, M. J. (Ed.). Anuran Communication. Smithsonian institution press, Washington and London: 205-219.

Manamendra-Arachchi, K. and R. Pethiyagoda, 1998. A synopsis of the Sri Lankan Bufonidae (Amphibia: Anura) with description of two new species. Journal of South Asian Natural History, 3 (2): 213-248.

Manamendra Arachchi, K. and R. Pethiyagoda, 2006. Sri Lankawe Ubhayajeevin "Amphibians of Sri Lanka" (text in sinhala). Wildlife Heritage Trust of Sri Lanka: $440+88$.

Meegaskumbura, M., F. Bossuyt, R. Pethiyagoda, K. Manamendra-Arachchi, M.M. Bahir, M.C. Milinkovitch and C.J. Schneider, 2002. Sri Lanka: an amphibian hotspot. Science: 298: 379.

Pough, F. H., R. M. Andrews, J. E. Cadle, M. L. Crump, A. H. Savitzky and K. D. Wells, 2004. Herpetology, Third Edition. Pearson Prentice Hall, USA: 726 